\title{
沈降管の沈降距離測定による粒子径分布解析
}

\author{
山本 哲也 ${ }^{1 *}$, 吉田 英人 ${ }^{2}$

\section{Particle Size Distribution Analysis by Sedimentation Distance Measurement in Sedimentation Tube}

Tetsuya Yamamoto ${ }^{1 *}$ and Hideto Yoshida ${ }^{2}$

Received 30 July 2018; Accepted 24 October 2018

\begin{abstract}
Tangent line method and Twomey's non-linear iteration method are applied to retrieve a particle size distribution from the sedimentation curve measured with a sedimentation distance in sedimentation tube. It is found that it is difficult to calculate the particle size distribution by the tangent line method using the sedimentation curve drawn from visual observation of the interface. On the other hand, the particle size distribution can be predicted numerically by Twomey method although the reliability is low. In order to improve the measurement accuracy, improved method to define the sedimentation interface using image analysis is investigated. Furthermore, introduction of correction term to Twomey method improves the reliability of the particle size distribution. As a results, this calculation method can be applied to measure particle size distribution not only for glass beads but also suspension concentrate of agricultural fungicide penthiopyrad.
\end{abstract}

Keywords: Particle size distribution, Sedimentation tube, Nonlinear iteration method data reduction.

\section{1. 緒言}

粉体の粒子径分布測定は, 顕微鏡法, レーザー回折・ 散乱法, 電気的検知帯法および篩い分け法などさまざま な測定法が実用化されている。顕微鏡法や篩い分け法は 完全に分散された粒子の場合, 正確な粒子径測定が可能 であるが, 測定検体の前処理など煩雑な作業を要する。 また, レーザー回折・散乱法や電気的検知帯法を利用し た測定装置は，測定が容易であり測定時間が短く再現性 が高いといった長所を有する反面, 複雑な演算処理を行 うために内部がブラックボックス化されている。さらに, これらはいずれも高価な測定装置となっている。

一方, 液相沈降法による粒子径分布測定法は, 重力ま たは遠心力による粒子の沈降速度からストークス径を測 定するため, 物理的意味が明瞭で信頼性の高い情報が得 られる。実際，液相沈降法の原理を用いた測定法は，簡 便に粒子径分布を測定できるため, さまざまな測定法が JIS にも採用されている。たとえば, 一様沈降式の測定

1 三井化学アグロ株式会社 研究開発本部 開発部

（ T 103-0027 東京都中央区日本橋一丁目 19 番 1 号)

Development Department, Research \& Development Division, MITSUI CHEMICALS AGRO, INC.

(1-19-1, Nihonbashi, Chuo-ku, Tokyo 103-0027, Japan) 2 広島大学大学院 工学研究科

（ T 739-8527 広島県東広島市鏡山 1-4-1）

Department of Chemical Engineering, Hiroshima University

(1-4-1, Kagamiyama, Higashi-hiroshima, Hiroshima 739-8527, Japan)

* Corresponding Author Tetsuya2.Yamamoto@mitsuichemicals.com
法としては, ピペット法（JIS Z8820-2:2004）, 此重計法 (JIS A1204:2009), 質量沈降法 (JIS Z8822:2001) および 液相重力沈降法（JIS Z8820-1:2002）が, また, ラインス タート式の測定法としては液相遠心沈降法（JIS Z8823-1:2001）が採用されている[1-4]。

液相一様沈降法による簡便な測定法としては Wernerの 方法がある。Wernerの方法では, 沈降粒子の高さが粒子 質量に比例すると仮定し, 篩上全粒子が沈降し終えた際 の粒子層の高さで, 任意時間の沈降粒子層高さで除すこ とで，積算粒子径分布を算出する[5]。また，研削といし 用研磨剤の粒子径の試験方法（JIS R6001-2:2017）の沈降 管試験方法では, 粒子の沈降高さを測定し, 標準粉体の 測定值と比較することで粒子径測定を行う試験法が採用 されている。しかし，液相における沈降界面すなわち， 沈降距離から粒子径分布を測定する手法については言及 されておらず, また, 沈降物の累積高さから得られた沈 降曲線の解析は十分には行われていなかった。

そこで, 本報では沈降管を用いた液相一様沈降法にお いて, 液相の沈降界面から読み取った沈降距離が粒子質 量に比例すると仮定し, 沈降距離を読み取り算出した沈 降曲線を 1) 接線法ならびに 2) 非線形反復法の一種であ る Twomey 法[6]を用いた解析により粒子径分布の算出を 試みた。また, これらの解析法を用いた粒子径分布の信 頼性の向上や測定時間の短縮の可能性について検討を 行った。さらに, 本手法が, 農薬製剤の粒子径分布測定 に適用可能かを検証した。 


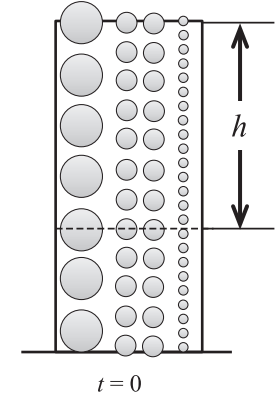

a) Initial condition

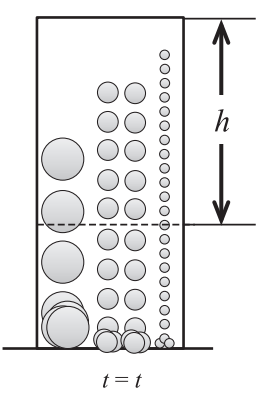

b) After certain time

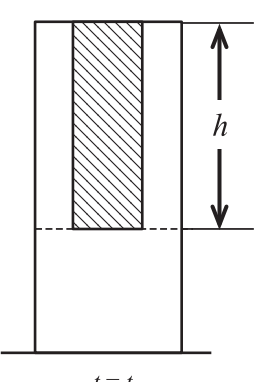

c) Image of integral type
Fig. 1 Principle of particle size measurement by sedimentation method

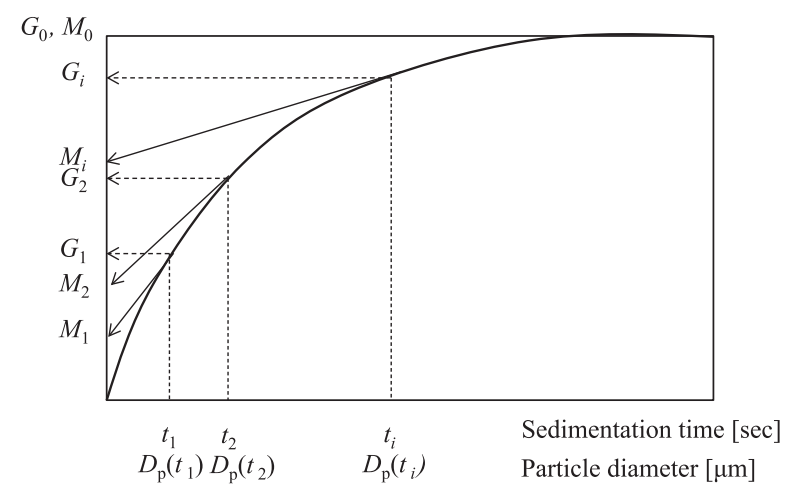

Fig. 2 Schematic diagram of sedimentation curve

\section{2. 理 論}

Fig. 1 に沈降法による粒子径分布の原理を示す。まず 試験粒子を適当な方法にて液体中に分散したのち静置す る。沈降天科法では, 一定時間経過後の沈降物の質量変 化を計測した後, 適当な方法で演算処理を行うことによ り粒子径分布の算出を行う。ここでの沈降距離の変化は, Fig. 1cにおける斜線部分の領域において質量変化の挙動 を計測していることになる。代表的な沈降曲線を Fig. 2 に示す。初期に存在した粒子がすべて沈降した場合の液 中粒子質量 $G_{0}$ は次式で表される。

$$
G_{0}=w \frac{v}{V} \frac{\rho_{\mathrm{p}}-\rho_{\mathrm{f}}}{\rho_{\mathrm{p}}}
$$

ただし， $w$ は空気中での粉体質量， $V$ は溶液体積を， $v$ は Fig. 1c における斜線部の体積, $\rho_{\mathrm{p}}, \rho_{\mathrm{f}}$ はそれぞれ粒子およ び分散媒の密度である。試料粉体の質量基準の粒子径分 布を $f\left(D_{\mathrm{p}}\right)$ とすると, 時刻 $t$ における沈降質量 $G(t)$ は Eq. (2) が成立する。ただし， $v\left(D_{\mathrm{p}}\right)$ は与えられる粒子の沈降 速度, $D_{\mathrm{p}}(t)$ は時間 $t$ において沈降距離 $h$ だけ沈降する粒 子のストークス径であり Eq. (3) で表される。

$$
\begin{aligned}
\frac{G(t)}{G_{0}} & =\int_{D_{\mathrm{p}}(t)}^{D_{\mathrm{p} m a x}} f\left(D_{\mathrm{p}}\right) \mathrm{d} D_{\mathrm{p}}+\int_{0}^{D_{\mathrm{p}}(t)} \frac{v\left(D_{\mathrm{p}}\right) t}{h} f\left(D_{\mathrm{p}}\right) \mathrm{d} D_{\mathrm{p}} \\
D_{\mathrm{p}}(t) & =\sqrt{\frac{18 \mu h}{\left(\rho_{\mathrm{p}}-\rho_{\mathrm{f}}\right) g t}}
\end{aligned}
$$

ただし， $\mu$ は分散媒粘度および $g$ は重力加速度を表して いる。Eq. (2) の右辺第一項は, 時刻 $t$ までに沈降が終了 する $D_{\mathrm{p}}(t)$ 以上の粒子の沈降質量であり, 第二項は粒子径 $D_{\mathrm{p}}(t)$ 以下の粒子の沈降質量を意味する。

ここで沈降曲線において時間 $t$ における接線を引き測 定初期における縦軸の交点を $M(t)$ とすると Eq. (2) は次式 となる。

$$
G(t)=M(t)+t \frac{\mathrm{d} G(t)}{\mathrm{d} t}
$$

ただし， $M(t)$ は次式で定義される值である。

$$
M(t)=G_{0} \int_{D_{\mathrm{p}}(t)}^{D_{\mathrm{pmax}}} f\left(D_{\mathrm{p}}\right) \mathrm{d} D_{p}
$$

したがって, 粒子径 $D_{\mathrm{p}}(t)$ における積算篩上分布は次式で 表される。

$$
R\left(D_{\mathrm{p}}(t)\right)=\frac{M(t)}{G_{0}}=\int_{D_{\mathrm{p}}(t)}^{D_{\mathrm{pmax}}} f\left(D_{\mathrm{p}}\right) \mathrm{d} D_{\mathrm{p}}
$$

異なる $n$ 点の時刻 $t_{\mathrm{i}}$ について Eq. (2) を適用し, 応答関数 $g\left(t, D_{\mathrm{p}}\right)$ を用いて変形すると Eq. (7) が得られる。

$$
\begin{aligned}
& \frac{G(t)}{G_{0}}=\int_{0}^{D_{\mathrm{p} m a x}} g\left(t_{\mathrm{i}}, D_{\mathrm{p}}\right) f\left(D_{\mathrm{p}}\right) \mathrm{d} D_{\mathrm{p}} \quad(i=1 \sim n) \\
& g\left(t, D_{\mathrm{p}}\right)=\frac{v\left(D_{\mathrm{p}}\right) t}{h} \quad\left(0<D_{p}<D_{p}\left(t_{i}\right)\right) \\
& g\left(t, D_{\mathrm{p}}\right)=1 \quad\left(D_{p}\left(t_{i}\right)<D_{p}<D_{\mathrm{p} \max }\right)
\end{aligned}
$$

$G(t) / G_{0}$ は, 実験により測定される值であり, 応答関数 $g\left(t, D_{\mathrm{p}}\right)$ は Eqs. (8-1), (8-2) に示すように既知であるので, 粒子径分布 $f\left(D_{\mathrm{p}}\right)$ を算出することが可能である。本報で は, 時間 $t$ における計測質量 $G(t)$ に替えてある時間にお ける沈降距離の測定值 $h$ を, 最終沈降質量 $G_{0}$ に替えて 最終沈降距離 $H_{0}$ を用いても粒子径分布の測定が可能と 仮定することで，すなわち Eq. (9) が成立すると仮定して 試験粉体の粒子径分布測定を行った。

$$
\frac{G(t)}{G_{0}}=\frac{h}{H_{0}}
$$

\section{3. 実験装置および方法}

Fig. 3 に実験装置の概略を示す。沈降管として $20 \mathrm{~mL}$ のメスシリンダーを用いた。粒子径分布測定法の妥当性 を評価するために Table 1 に示す 3 種類のガラスビーズ 標準粒子の粒子径分布を測定した[7]。

室温 $20^{\circ} \mathrm{C}$ の条件下, 試料粉体を設定した試料濃度と なるように科量し， 0.5 mass\%へキサメタリン酸ナトリウ 么水溶液を所定量加えて懸濁し， ガラス棒にて擋拌しな がら 10 分間超音波分散（周波数 $40 \mathrm{kHz}$, 出力 $40 \mathrm{~W}$ ）を した後, 素早く沈降管に移し替え, 水平な面に静置する と同時に測定を開始した。沈降距離の測定は，界面の読 み取りを容易とするために黒色背景の前に沈降管を設置 し,さらに沈降管上部より 200 ルクス以上の LED ライト 


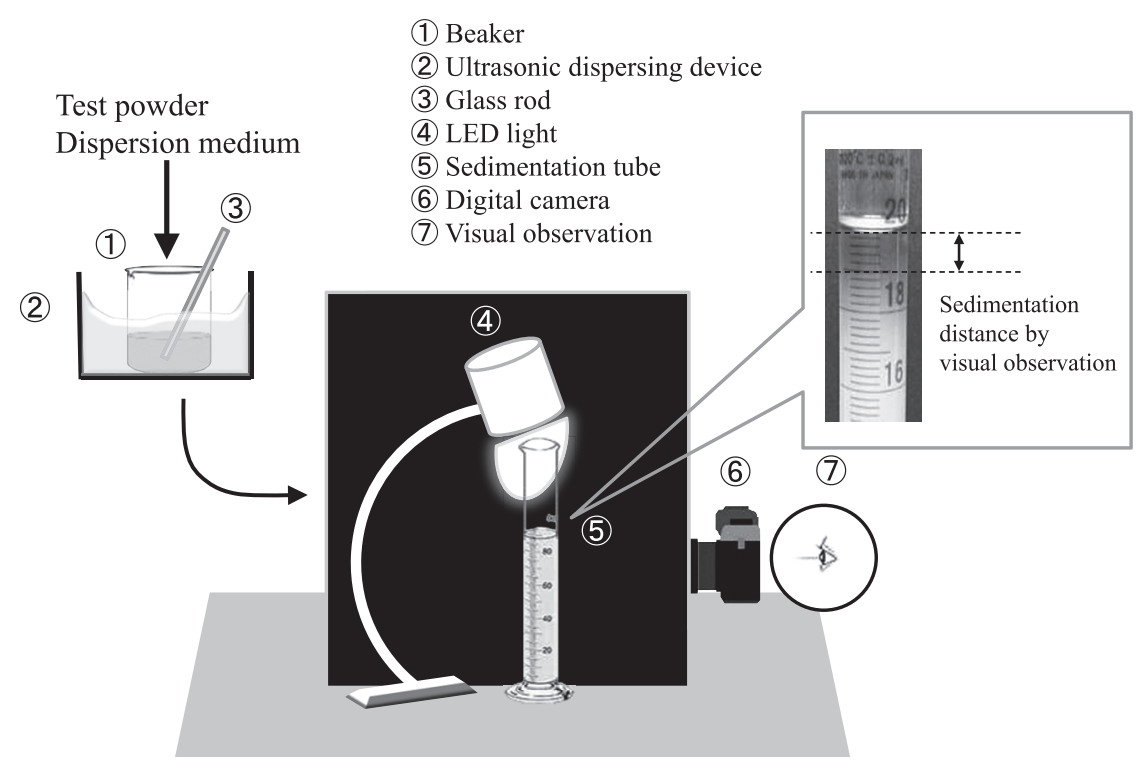

Fig. 3 Schematic diagram of experimental set-up

にて光の照射を行った。沈降距離は設定した最終沈降距 離に達するまで, 経時的に目視にて読み取るとともにデ ジタルカメラにて沈降管の撮影を行った。なお， Fig. 3 のように, 気液界面から完全に澄明な液相と懸濁が認め られる液相との界面までの距離を目視での沈降距離とし て測定した。測定終了後に, 沈降距離を指標とした沈降 曲線を描画し，接線法ならびに非線形反復法である Twomey 法を用いた解析により粒子径分布の算出につい て検討を行った[8,9]。なお，接線法ならびに Twomey 法 による粒子径分布の算出では $20^{\circ} \mathrm{C}$ の水の密度の $\rho_{\mathrm{f}}=$ $998 \mathrm{~kg} / \mathrm{m}^{3}$ ，粘度 $\mu=1.0 \times 10^{-3} \mathrm{~Pa} \cdot \mathrm{s}$ と設定して算出した。

\section{4. 実験結果および考察}

\section{1 接線法による粒子径分布解析}

3 種類のガラスビーズ標準粒子について, 1.5 mass\%の 懸濁液を作製し界面を読及取り沈降曲線の描画を行っ た。MBP 10-100 標準粒子において, 最終沈降距離 $H_{0}$ を $8 \mathrm{~cm}$ としてプロットした沈降曲線および接線法により算 出した粒子径分布と走査型電子顕微鏡（SEM）により測 定した粒子径分布を比較した結果を Fig. 4 に示す。 Fig. 4a に示した沈降曲線は, 目視で読み取った界面すな わち沈降距離が時間経過とともに増加し, 二次曲線で近 似可能な沈降挙動を示したことから，接線法による粒子 径分布測定が可能であった。Fig. $4 \mathrm{~b}$ に示した接線法によ り算出された粒子径分布は, SEMにより測定した実測値 と近似した粒子径分布を示したものの，計算值はより粒 子径が小さい領域にシフトしており, 正確な粒子径分布 は得られなかった。これは, 目視で読み取った沈降距離 は完全に澄明な液相と懸濁層の界面と気液界面の距離を 測定しているため, 実際の沈降距離と異なり, 真の界面 は目視よりも沈降距離が長い領域に存在するために生じ たと推測された。Fig. 5 に MBP 1-10 および MBP3-30 標 準粒子に打いて最終沈降距離 $H_{0}$ を $8 \mathrm{~cm}$ としてプロット した沈降曲線および実験值の近似曲線を示す。目視で読
Table 1 Properties of tested particles

\begin{tabular}{lcc}
\hline & Mass median diameter $[\mu \mathrm{m}]^{*}$ & True density $\left[\mathrm{kg} / \mathrm{m}^{3}\right]$ \\
\hline MBP 1-10 & 4.75 & $4000-4200$ \\
MBP 3-30 & 13.10 & $4000-4200$ \\
MBP 10-100 & 36.39 & $4000-4200$ \\
\hline
\end{tabular}

* Measured by Scanning Electron Microscope (SEM)

* Measurement condition

Magnification (MBP 1-10: 1500, MBP 3-30: 500, MBP 10-100: 200) Number of particle (MBP 1-10: 55728, MBP 3-30: 50685, MBP 10-100: 51002)

み取った沈降距離は, 時間経過とともに増加したが, MBP 10-100 と異なりほぼ直線的に上昇し, 直線近似で高 い相関が得られた。そのため, 接線法による粒子径分布 解析を試みたが，接線を描画することができず，粒子径 分布解析結果を得ることはできなかった。比較的粒子径 の大きい MBP 10-100 標準粒子では接線法を用いた粒子 径測定の可能性が示唆されたものの, MBP 3-30 および MBP 1-10 標準粒子の粒子径分布測定は不可であった。す なわち, 目視で読み取った沈降距離から描画した沈降曲 線を用いて接線法にて解析することで粒子径分布を算出 する手法は汎用的に使用するのは困難であることがわ かった。

\subsection{Twomey 法による粒子径分布解析}

\subsubsection{Twomey 法の適用評価}

Figs. 4, 5 で得られた沈降曲線を用いて Twomey 法によ る粒子径分布解析を行った。なお， Twomey 法における 反復計算の範囲を $0.1 \sim 500 \mu \mathrm{m}$, 粒径分割数を 100 , 沈降 距離測定点数を 12 点とし, 最終沈降距離 $H_{0}$ はそれぞれ 測定した最後の沈降距離に設定して計算を行った。Fig. 6 に3 種のガラスビーズ標準粒子の計算結果を SEM にて 測定した粒子径分布を比較した図を示す。Twomey 法に より算出した粒子径分布は,いずれの粒子径のガラスビー ズに扔いても実測值と近似した形状を描いたが, 実測值 よりも粒子径が小さい領域にシフトした分布が得られた。 


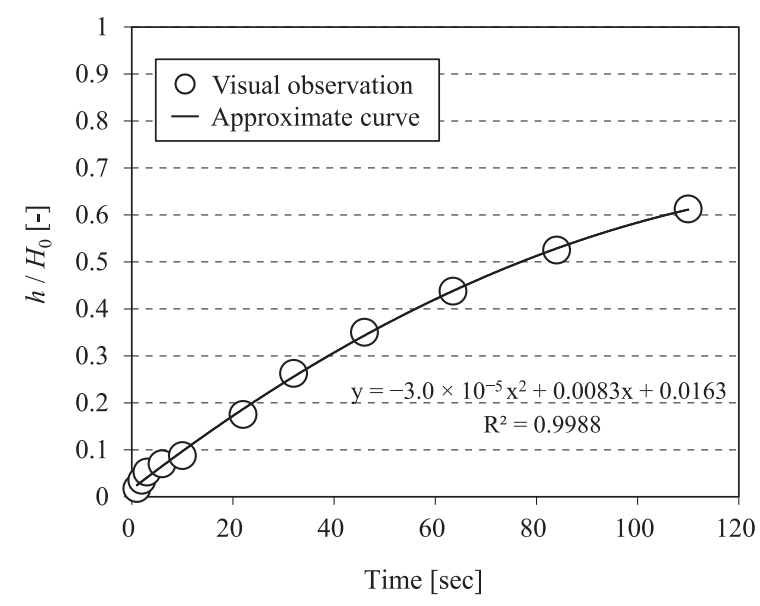

(a) Sedimentation curve by visual observation

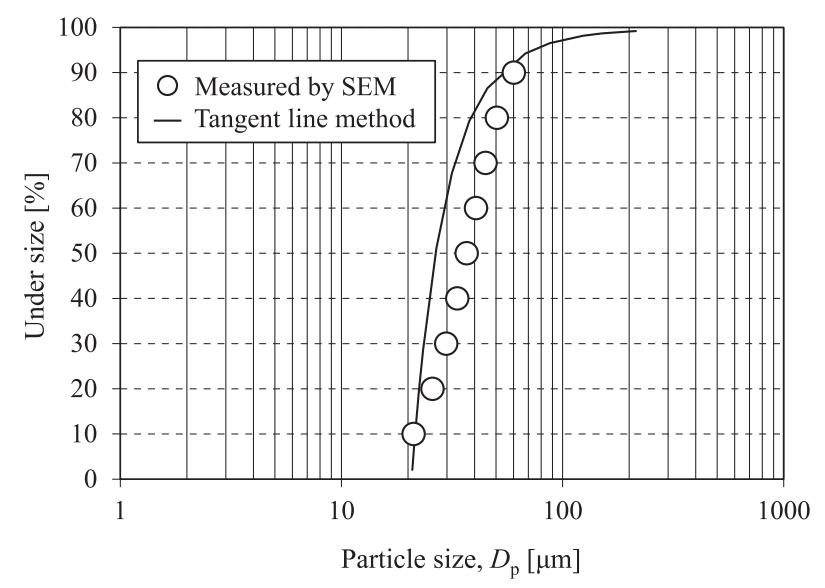

(b) Comparison of particle size distribution

Fig. 4 Calculation of particle size distribution by tangent line method for MBP 10-100 based on visual observation

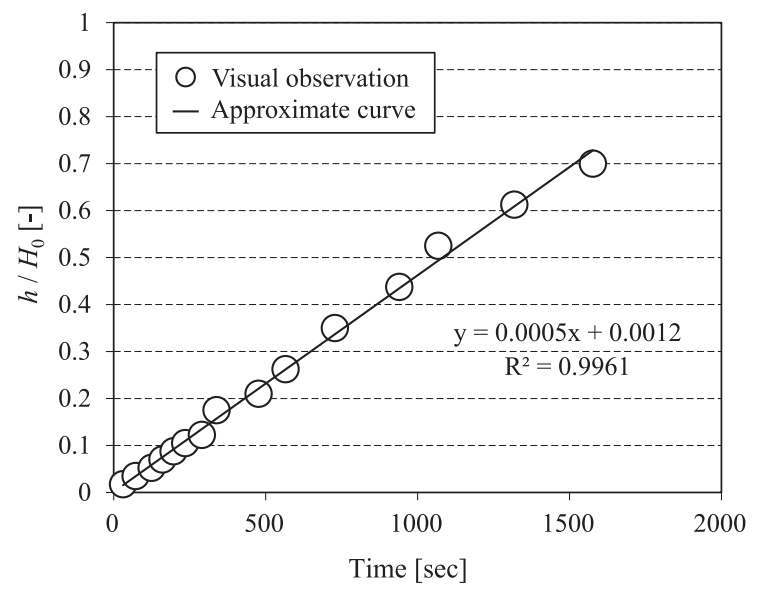

(a) MBP 3-30

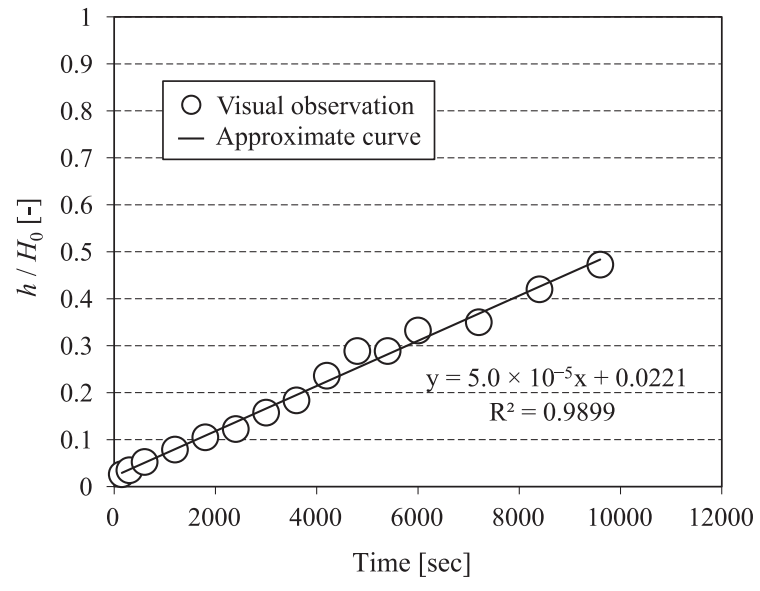

(b) MBP 1-10

Fig. 5 Sedimentation curve for MBP 3-30 and MBP1-10 by visual observation

4.1 で述べたように, 粒子径分布測定が不可であった接線 法とは異なり, Twomey 法を用いることで, SEM 測定值 に近似した粒子径分布を得られる可能性が示唆された。 一方で, SEM 測定值との中位径の差は大きく, その信頼 性は十分なものではなかった。液相一様沈降法である Wernerの方法では, 篩上全粒子が沈降し終えた際の粒子 層の高さで, 任意時間の沈降粒子層高さを除すことで, 積算粒子径分布を算出していた。一方，本報の沈降管に よる測定法では，すべての粒子が沈降した距離を沈降距 離として目視で読み取っているため, 目視で得られた沈 降界面は, 実際の粒子の沈降界面よりも遅れて現れてい ると考えられた。すなわち目視では捉えられない界面が 存在すると仮定し, 画像色解析を用いた界面の読み取り による粒子径分布解析を行った。

\subsection{2 画像色解析による界面の設定}

沈降距離の読み取りを沈降界面の画像色解析による判 定にて行った。3の実験方法に従い沈降管試験を実施し, 一定時間ごとに沈降界面付近をデジタルカメラ（画素数 1000 万以上）で撮影した。本報では, 簡便かつ安価な粒 子径測定法の確立を目的としている。そこで, 画像色解 析はインターネットに無料で公開されている画像解析ソ
フト（Color-Sample.com）を用いた。

画像色解析サイト (https://www.color-sample.com/others/ imageanalysis/) にアクセスし, 撮影した沈降管の写真を Web ページの画像色解析領域にドラッグする。ドラッグ した写真にカーソルを合わせることで, カーソル位置の 画像色に関する情報を得ることができる。画像色解析を 実施するにあたり, まず目視で得られる界面が, 画像色 解析では，どのように定義できるかを評価した。その結 果, RGB カラーモデルを用いて, 目視の沈降距離が定義 できることがわかった。すなわち, 赤 (Red), 緑 (Green), 青（Blue）それぞれの数值が, 150 を下回る地 点を界面（以下 RGB150 界面）として読み取った場合に 目視での界面読み取りに近い值を示すことが判明した。 Fig. 7 に 3 種の標準粒子において, 目視で読み取った沈 降距離と RGB150 界面で読み取った沈降距離の比較図を 示す。いずれの標準粒子の結果においても, 目視の界面 とRGB150 界面の值はほぼ一致していることがわかる。 このように画像色解析にて目視と同様の色調判別が可能 であることが判明したことから，つぎに目視で捉えられ ない界面を画像色解析にて設定することで, 粒子径分布 の信頼性向上を検討した。目視で得られた沈降距離を用 


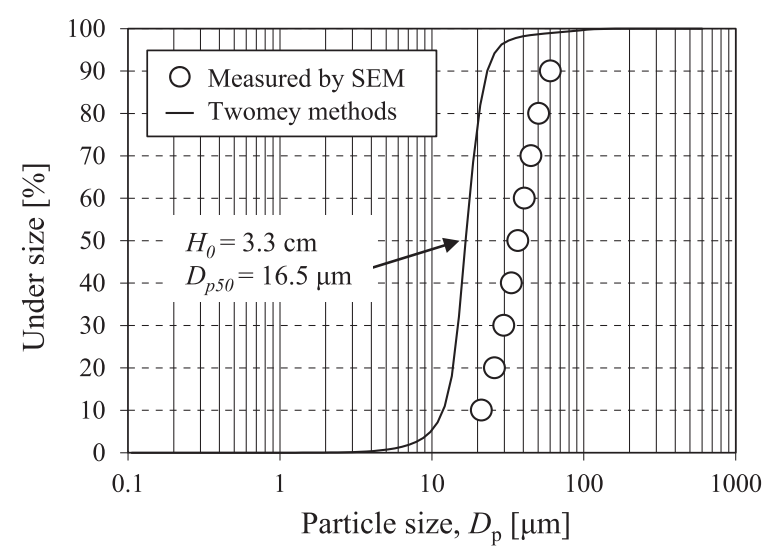

(a) MBP $10-100$

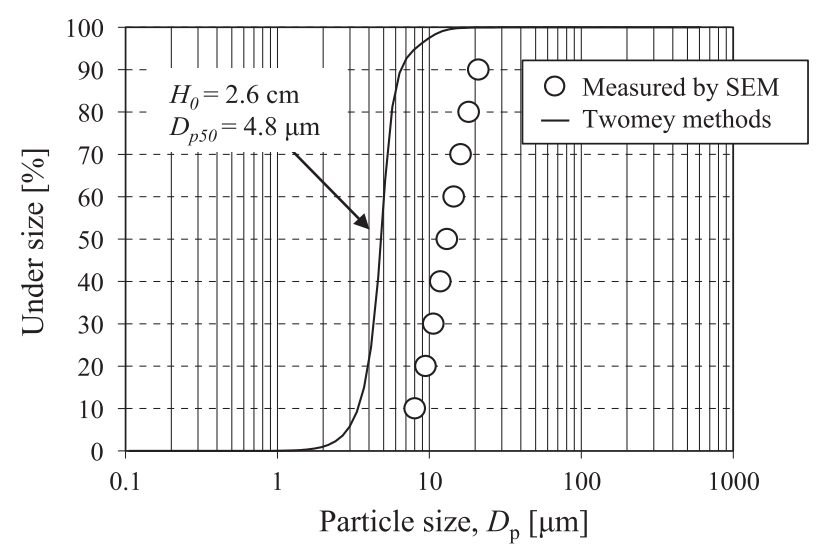

(b) MBP 3-30

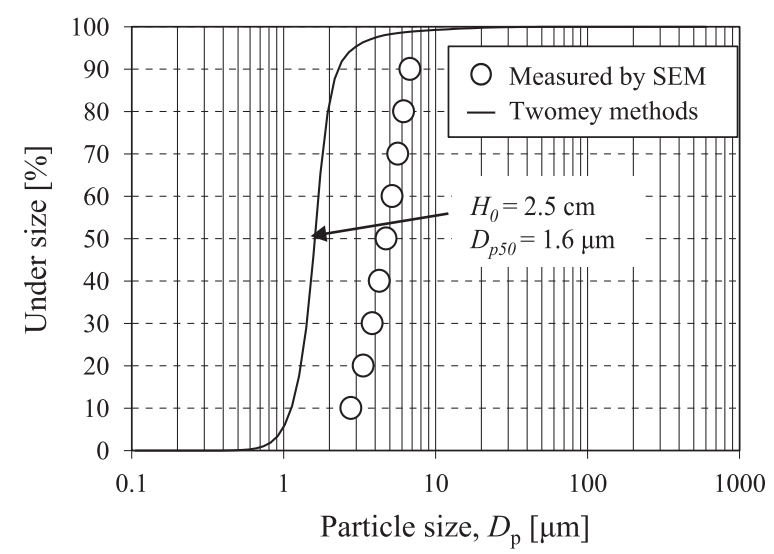

(c) MBP 1-10

Fig. 6 Comparison of measured and calculated distribution for each standard particle on visual observation

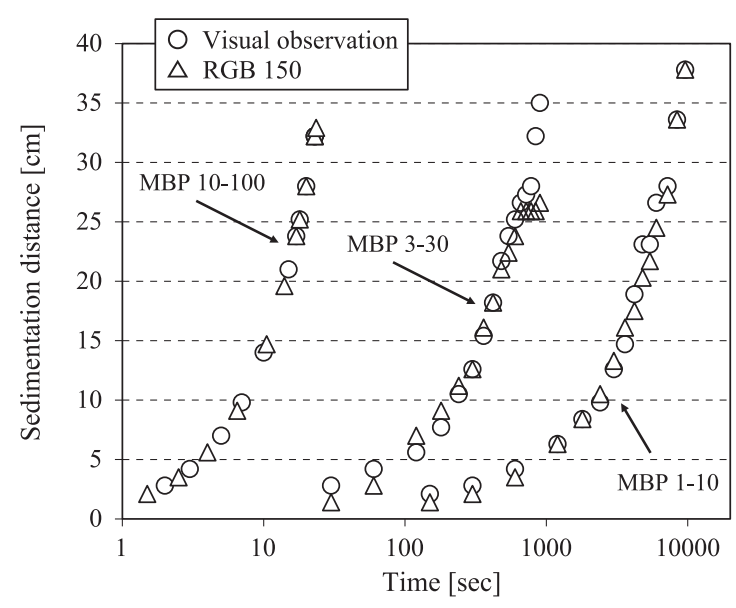

Fig. 7 Comparison of sedimentation distance measured by visual observation and image analysis based on RGB150 for each standard particle

いて算出した粒子径分布は実測值よりも微細粒子径領域 にシフトしていることから, 真の沈降距離は目視で得ら れる沈降距離よりも大きい值である推定される。したがっ て, RGBの数值が高い, すなわち粒子懸濁層下部に真の 界面があると考えられた。また，撮影した沈降管の懸濁 層において RGB 值は, 沈降管上部の液面から沈降管下 部に向かうにつれて上昇し, 一定值に漸近する傾向にあ ることがわかった。このことから，Fig. 8 に示すように
(A)

(B)

(C)

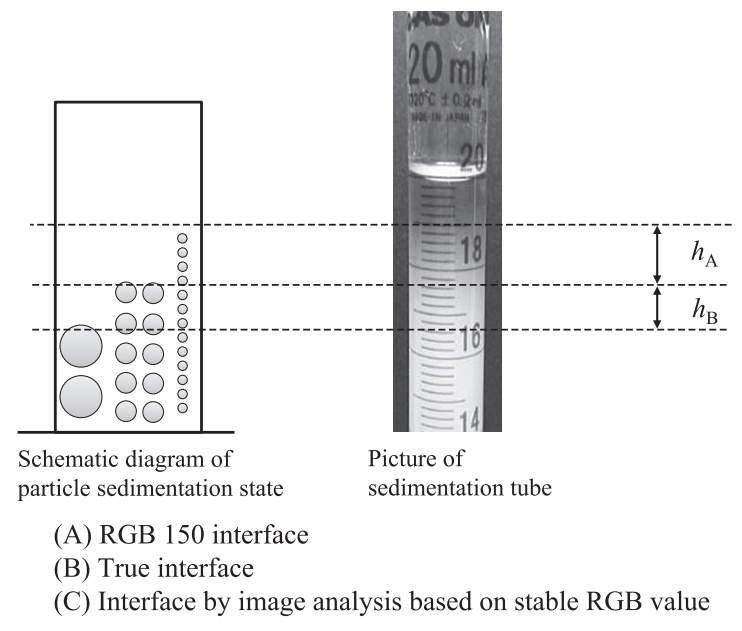

Fig. 8 Definition of interface by image analysis

RGB150 の界面と RGB 值が一定となる界面に挟まれた領 域に沈降界面が存在すると仮定し, RGB150 界面から真 の界面までの距離を $h_{\mathrm{A}}$, 真の界面から RGB が一定とな る界面までの距離 $h_{\mathrm{B}}$ と定義した。 $h_{\mathrm{A}}$ と $h_{\mathrm{B}}$ の比率を変動 させて算出した界面を用いて Twomey 法により粒子径分 布を算出した結果, $h_{\mathrm{A}}: h_{\mathrm{B}}=8: 2$ と設定した場合にいず れの標準粒子においても実測值に近い形状の粒子径分布 を示す傾向であった。 $h_{\mathrm{A}}: h_{\mathrm{B}}=8: 2$ と設定した界面にて Twomey 法により算出した各標準粒子の粒子径分布を 


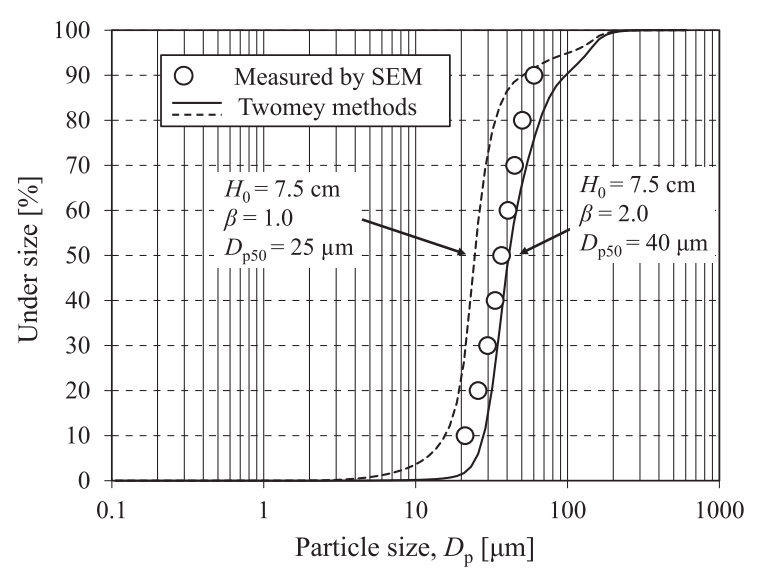

Fig. 9 Effect of calculated interface and correction coefficient on particle size distributions for MBP10-100

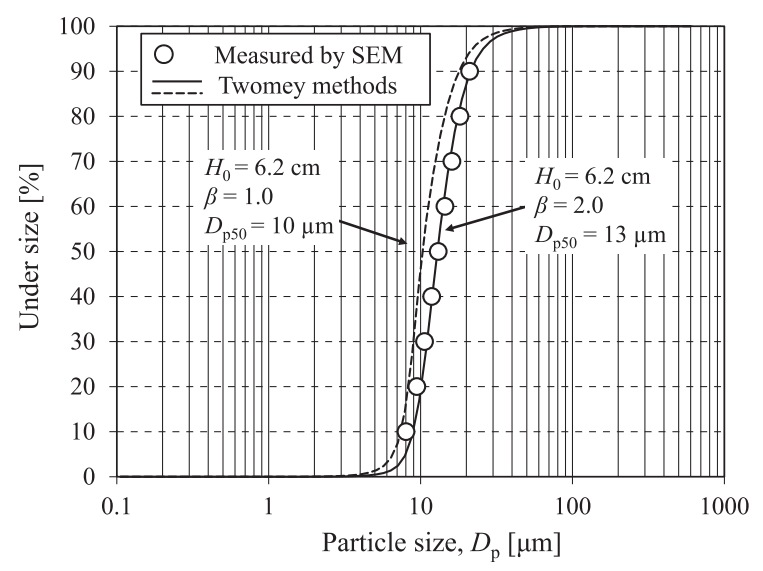

Fig. 10 Effect of calculated interface and correction coefficient on particle size distributions for MBP 3-30

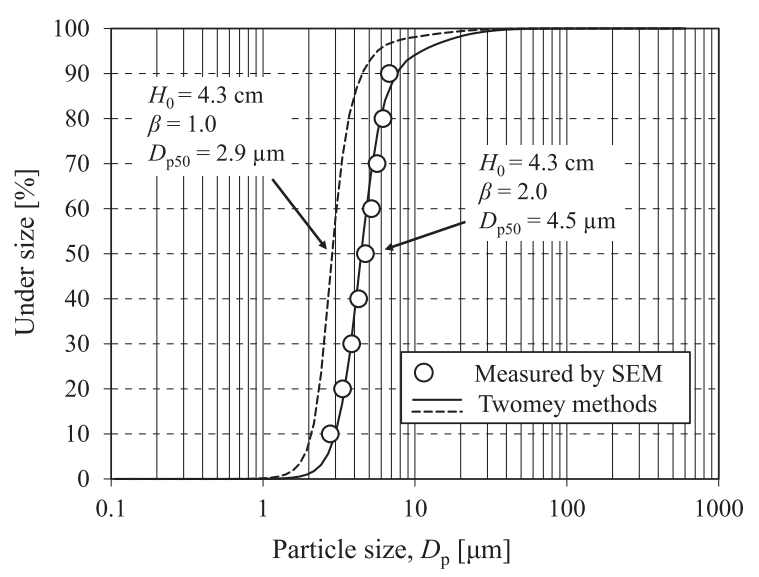

Fig. 11 Effect of calculated interface and correction coefficient on particle size distributions for MBP 1-10

Figs. 9〜11 に示す。図中の破線が新たに設定した界面よ り算出した粒子径分布を表している。実測值に漸近した 值を示したものの, さらなる改良の余地があると考えら れた。そこで, RGB 值以外の画像色ファクターでの界面 の判別法の導入も検討したがよい指標を見出すことはで きなかった。

\subsubsection{Twomey 法への修正項の導入}

4.2.2の検討の結果, 画像色解析による界面の設定のみ

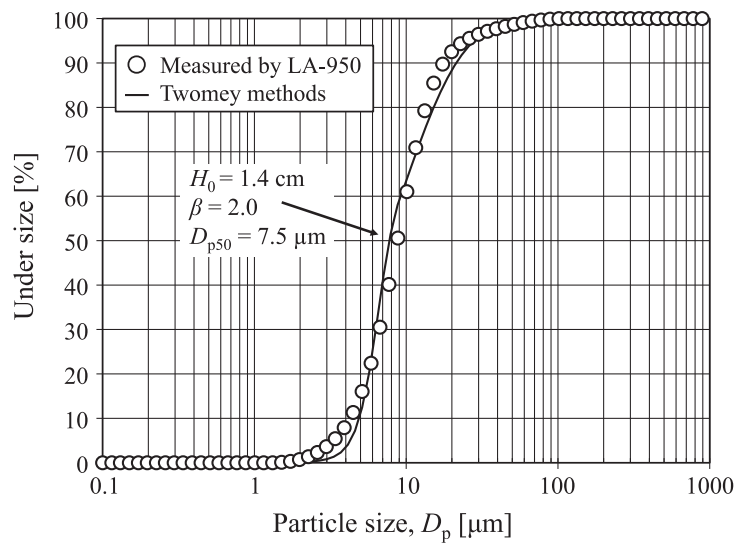

Fig. 12 Comparison of measured and calculated distribution for penthiopyrad suspension concentrate

Table 2 Recipe of penthiopyrad suspension concentrate

\begin{tabular}{lc}
\hline \multicolumn{1}{c}{ Component } & Recipe [\%] \\
\hline Pulverized penthiopyrad TG (99.7\%) & 20.1 \\
SOPROPHOR FLK ${ }^{1)}$ & 1.0 \\
SURFYNOL104PG-502) & 0.1 \\
Deionized water & 78.8 \\
\hline
\end{tabular}

1) Ethoxylated tristyrylphenol phosphate potassium salt produced by Solvey

2) Tetramethyl-5-decyne-4,7-diol produced by Evonik

では実測值の信頼性は十分ではないことが示唆された。 これまでは, 沈降質量と沈降距離が比例し, Eq. (9) が成 り立つとの仮定に基づき，演算を行ってきたが，次式の ように修正項を設けることで信頼性の向上の検討を行っ た。

$$
\frac{G(t)}{G_{0}}=\beta \frac{h}{H_{0}}
$$

ただし， $\beta$ は Twomey 法の演算時に導入する修正項であ り, 沈降距離比を沈降質量比に換算する上での補正係数 を意味している。沈降界面の設定および修正項の導入の 検討を行いSEM 測定值と比較した結果を Figs. 9〜11に 実線で示した。修正項として 2.0 と設定することで，い ずれの標準粒子においてもSEM 測定值と良好に近似し た值が得られ，特に中位径の算出を目的とした場合には 高い精度で粒子径予測が可能となった。つぎに得られた 測定法を用いて農薬懸濁水性ゾルの粒子径分布測定が可 能かを確認した。

\section{3 沈降法による農薬懸濁水性ゾルの粒子径分布測定}

農業用殺菌剂ペンチオピラドを 20 mass\%配合した水性 矁濁ゾル $\left(D_{\mathrm{p} 50}=8.7 \mu \mathrm{m}\right)$ を作製し, 得られた水性懸濁ゾ ルの粒子径分布を評価した。Table 2 に作製したペンチオ ピラド水性懸濁ゾルの処方を示す。農薬製剤の粒子径測 定は, 一般的に Fraunhofer 回折および Mie 散乱理論を利 用したレーザー回折・散乱式粒子径分布測定装置が用い られていることから, HORIBA LA-950（堀場製作所（株） 製）を用いて測定した粒子径分布を実測值として, 沈降 管を用いた沈降距離測定から粒子径分布解析を行った。 ペンチオピラド水性懸濁ゾル $0.5 \mathrm{~g}$ をポリオキシエチレン 


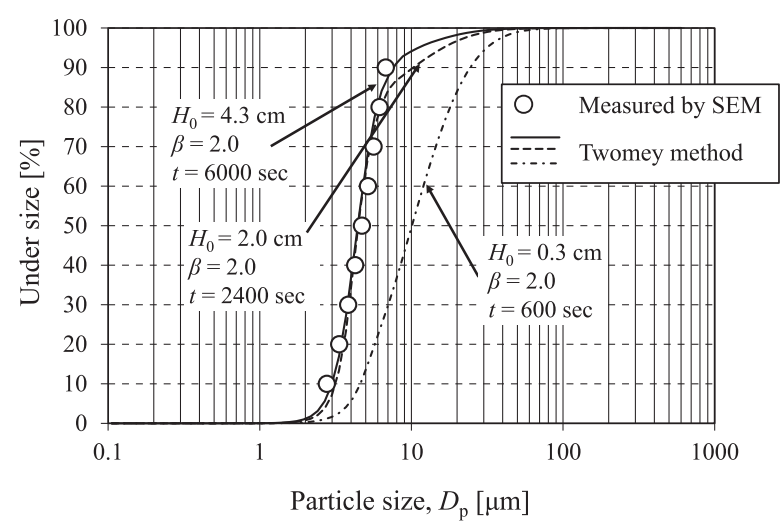

Fig. 13 Effect of measurement time on particle size distribution for MBP1-10

ノニルフェニルエーテル塩（ニューコール 560, 日本乳 化剂（株））の $0.2 \mathrm{w} / \mathrm{v} \%$ 水溶液 $100 \mathrm{~mL}$ を用いて分散さ せ，超音波分散（周波数 $40 \mathrm{kHz}$, 出力 $40 \mathrm{~W}$ ） 5 分間 行った検体を LA-950（屈折率 1.6 設定）にて透過率が約 90\%条件となるように添加して測定した。沈降管を用い た粒子径分布測定は, 標準粒子と同様の条件下でペンチ オピラド水性懸濁ゾルをペンチオピラドが $1.5 \mathrm{mass} \%$ と なるようにへキサメタリン酸 $0.5 \mathrm{mass} \%$ 水溶液で希釈し た溶液を試験検体として測定を行った。なお, ペンチオ ピラドの密度は, $\rho_{\mathrm{p}}=1270 \mathrm{~kg} / \mathrm{m}^{3}$ として算出した。Fig. 12 に実測值と 4.2 で設定した解析法を用いて沈降距離測定 により算出した粒子径分布の比較を示す。標準粒子の結 果と同様にペンチオピラド水性懸濁ゾルの測定において も高い相関を示す結果が得られた。

\section{4 測定時間短縮の検討}

沈降管の沈降距離を測定し, 4.2 で設定した条件下で測 定を行うことで信頼性の高い粒子径分布の測定が可能と なることが示唆された。一方で, 比較的粒子径が微細な MBP 1-10 やペンチオピラド水性懸濁ゾルでは, 沈降界面 を捉えるために測定時間が長くなる傾向にあった。そこ で, 沈降距離の測定時間の短縮ならびに測定回数の削減 が可能かの検討を行った。Figs. 13, 14 にMBP 1-10 およ びペンチオピラド水性懸濁ゾルにおいて，測定時間を短 縮した場合の粒子径分布算出結果を示す。MBP 1-10で は, 測定時間を初期の 6000 秒（測定回数 12 回）から 2400 秒（測定回数 6 回, 沈降距離 $2 \mathrm{~cm}$ ）に短縮した場 合，すなわち測定試料の $90 \%$ ふるい下積算粒子径にあた る約 $7 \mu \mathrm{m}$ よりも大きな粒子を対象とした測定でも高い 信頼性を維持した。一方, 測定時間を 600 秒（測定回数 3 回, 沈降距離 $0.3 \mathrm{~cm}$ ）まで短縮すると実測值との乘離

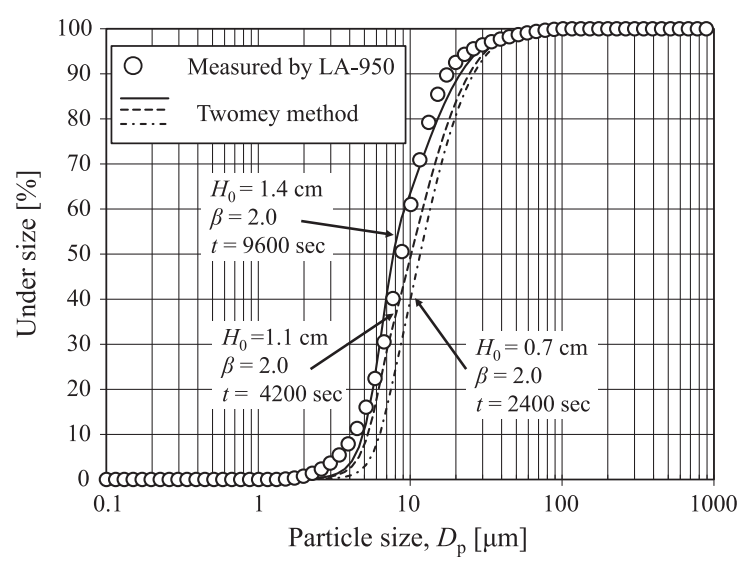

Fig. 14 Effect of measurement time on particle size distribution for penthiopyrad suspension concentrate

が大きくなる傾向にあった。また, ペンチオピラド水性 懸濁ゾルでは測定時間を初期の 9600 秒から 2400 秒（測 定回数 3 回, 沈降距離 $0.7 \mathrm{~cm}$ ) すなわち測定試料の $80 \%$

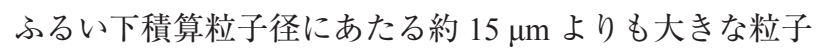
のみの測定においても, 高い信頼性を維持した。この結 果から, 測定試料の $80 \%$ ふるい下積算粒子径以上の粒子 径を持つ粒子の沈降距離を測定することで, 今回供試し た単峰性の粒子径分布を持つ検体であれば，実用上問題 ない信頼性が得られることが示唆された。

\section{5. 結言}

沈降管を用いた液相一様沈降法を用いて，液相の沈降 距離から粒子径分布を算出する手法について 3 種のガラ スビーズ標準粒子およびペンチオピラド水性懸濁ゾルを 用いて検討し，以下の知見を得た。

（1）沈降界面の画像色解析を行い, RGB 值が 150 となる 界面と RGB が一定となる界面の間に設定した沈降 界面を用いて, Twomey 法を用いた数值解析を行う ことで粒子径分布の算出は可能となる場合がある。

（2）上記において Twomey 法に修正項 $\beta$ に 2.0 を適用す ることで，粒子径分布の信頼性が向上する。

(3) 得られた測定手法にて農業用殺菌剂ペンチオピラド 水性懸濁ゾルの粒子径分布の測定も可能である。

（4）測定時間を要する微細粒子の場合，測定試料の $80 \%$ ふるい下積算粒子径以上の粒子径を持つ粒子の沈降 距離を測定することで実用上問題ない信頼性を得ら れることがある。

（5）目視で読み取った沈降距離から描画した沈降曲線を 用いて接線法にて粒子径分布を算出するのは困難で ある。

\section{Nomenclature}

$D_{\mathrm{p}} \quad$ : Particle diameter

$D_{\text {pmax }} \quad$ : Maximum particle diameter

$D_{\mathrm{p} 50} \quad$ : Mass median diameter

$D_{\mathrm{p}}(t) \quad$ : Critical particle diameter $[\mu \mathrm{m}]$

$[\mu \mathrm{m}]$

$[\mu \mathrm{m}]$

$[\mu \mathrm{m}]$
$f\left(D_{\mathrm{p}}\right)$

: Frequency size distribution

$\left[\mu \mathrm{m}^{-1}\right]$

$G(t) \quad$ : Sedimentation mass

$G_{0} \quad$ : Total sedimentation mass

$g \quad$ : Gravity acceleration $[\mathrm{kg}]$

[kg] $\left[\mathrm{m} / \mathrm{s}^{2}\right]$ 
$g\left(t, D_{\mathrm{p}}\right):$ Response function

$H_{0} \quad$ : Total sedimentation distance

$h \quad:$ Sedimentation distance

$M(t) \quad$ : Sedimentation mass calculated by tangent line method

$n \quad:$ Number of sedimentation data

$R\left(D_{\mathrm{p}}\right)(t)$ : Oversize integrated distribution

$t \quad:$ Time
[-] $\quad V \quad$ : Volume of solution

[m] $\quad v\left(D_{\mathrm{p}}\right) \quad:$ Terminal settling velocity

$[\mathrm{m} / \mathrm{s}]$

[m] $\quad w \quad$ : Mass of particle

$[\mathrm{kg}]$

$\beta \quad$ : Correction coefficient

[kg] $\quad \mu \quad$ : Viscosity

$[\mathrm{Pa} \cdot \mathrm{s}]$

[-] $\quad \rho_{\mathrm{p}} \quad$ : Density of particle

$\left[\mathrm{kg} / \mathrm{m}^{3}\right]$

$[-] \quad \rho_{\mathrm{f}} \quad$ : Density of fluid

$\left[\mathrm{kg} / \mathrm{m}^{3}\right]$

\section{References}

[1] K. Fukui, H. Mizuta, M. Shiba, C. Yun, H. Yoshida, Data reduction in measurement of size distribution using sedimentation balance method, J. Chem. Eng., Japan 24 (1998) 928-933.

[2] K. Fukui, H. Yoshida, M. Shiba, Y. Tokunaga, Investigation about data reduction and sedimentation distance of sedimentation balance method, J. Chem. Eng., Japan 33 (2000) 393-399.

[3] K. Fukui, H. Yoshida, Y. Tokunaga, Influence of the behavior of particles and dispersion medium on the particle size measurement with the sedimentation balance method, J. Chem. Eng., Japan 28 (2002) 161-167.

[4] Japanese industrial standard, Z8822, Determination of particle size distribution by the mass of sediment-particles in liquid, Japanese standards association, Japan (2000).

[5] K. Iinoya, Funtai Kogaku Handbook, Asakura Shoten (1966) pp.25-26.
[6] S. Twomey, Comparison of constrained linear inversion and an iterative nonlinear algorithm applied to the indirect estimation of particle size distributions, J. Comput. Phys. 18 (1975) 188-200.

[7] H. Yoshida, H. Matsuda, K. Fukui, Y. Tokunaga, Particle size measurement with an improved sedimentation balance method and microscopic method together with computer simulation of necessary sample size, Adv. Powder Technol. 12 (2001) 79-94.

[8] S. Tohno, Data inversion on the measurement of the size distribution of aerosols, Earozoru Kenkyu 12 (1997) 281287.

[9] H. Tsuji, H. Makino, H.Yoshida, K.Iinoya, An advanced method for measurement of the particle size distribution by anisokinetic sampling - Investigation of a method using three probes with different diameter-, J. Soc. Powder Technol., Japan 34 (1997) 904-912. 